\title{
EFFECT OF FINANCIAL LITERACY AND FINANCIAL BEHAVIOR OF FINANCIAL SATISFACTION AT PROFESSIONAL BASKETBALL ATHLETES INDONESIA
}

\author{
Margerita Wenny Jessica ${ }^{1}$, Njo Anastasia ${ }^{2}$, Dewi Pertiwi ${ }^{3}$ \\ 1,2,3 Finance and Investment Program, Faculty of Business and Economics, Petra Christian University \\ Jl. Siwalankerto 121-131, Surabaya

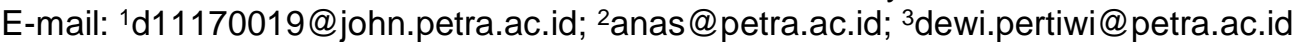

\begin{abstract}
This study aims to determine the effect of financial literacy and financial Behavior on Indonesian professional basketball athletes. The population in this study is Indonesian professional basketball athletes who are the members of the Indonesian Basketball League (IBL) 2021. The sample in this study is Indonesian professional basketball athletes who have credit cards and investments. Sources of data in this study through the distribution of questionnaires. The data analysis method uses analysis Partial Least Square (PLS). This analysis shows that financial literacy and financial behavior have a significant effect on financial satisfaction.
\end{abstract}

Keywords: Financial Behavior, Financial Literacy, Financial Satisfaction.

\section{INTRODUCTION}

An athlete is involved in sports activities by getting achievements in sports (Yuwanto \& Sutanto, 2012). According to the KBBI, a professional requires special skills in carrying out an activity or job and is also a professional related to a profession. According to Article 1 number 15 of the Law of the Republic of Indonesia No. 3 of 2005 concerning the National Sports System, Professional sports are "sports carried out to earn income in the form of money or other forms based on sports skills". Professional athletes can provide large incomes during their careers and retirement based on this description. This is because athletes can earn income from their profession as athletes.

Not all professional basketball athletes have great incomes, and not all professional basketball athletes have the good fortune in retirement. Michael Jordan is one of the former professional basketball athletes who is listed as the richest athlete in history according to CNN Indonesia (2020), and his success is a benchmark for other professional athletes. Jordan is one of the athletes with balanced success while still active in the basketball world and retirement (CNN Indonesia, 2020).

Darius Miles is one example of a former professional basketball athlete who entered the NBA 16 years ago but had to experience the opposite in his retirement. Darius Miles went bankrupt five years after his retirement. The bankruptcy experienced by Miles was due to his dependents that were twice as large as his assets. It is known that Miles still has $\$ 20,000$ in childcare debt and suffered a loss of $\$ 100,000$ in 2008 due to his real estate business (Rosyidan, 2016). The bankruptcy and arrears he experienced showed that Miles had not managed his finances properly, which resulted in him not fulfilling his financial satisfaction. According to Adonal Foyle, former Vice President of the NBA Players Association, an athlete, especially a professional athlete, does have a heyday in accumulating wealth and should be able to find out the best way to make his wealth last forever and education is the key (Rosyidan, 2016).

Financial satisfaction someone must have different levels and achievements. According to VanPraag \& Ferrer-i-Carbonell (2011), financial satisfaction is a person's level of satisfaction with their financial condition. According to Hira \& Mugenda (1998), the concept of financial satisfaction is measured by using one or several indicators to measure a person's level of satisfaction, such as satisfaction with his income and satisfaction with the financial situation in general or satisfaction with his current life. A person with less income is not necessarily dissatisfied with his financial condition and vice versa. This is because the level of financial satisfaction that everyone has is different. 
According to Ali et al. (2014), financial literacy affects and becomes one of the important determinants of one's financial satisfaction. Financial literacy is knowledge to manage finances in making financial decisions (Chen \& Volpe, 1998; Wahono \& Pertiwi, 2020). Mason \& Wilson (in Krishna et al., (2010) say financial literacy is a person's ability to obtain, understand and evaluate relevant information to decide by understanding the financial consequences that can arise. An Indonesian professional basketball athlete needs to understand good financial literacy, using general financial knowledge, knowledge about saving and borrowing, knowledge about insurance, and knowledge about investment as a benchmark for financial literacy so that they can achieve good financial satisfaction thanks to understanding good financial literacy. Research belonging to Falahati et al. (2012) shows that financial behavior affects a person's financial satisfaction. Ackert \& Deave (2010) say financial behavior is a psychological approach to explain how a person's behavior affects decisions in financial matters that can affect a person's welfare. Arifin (2018) states that financial behavior has a significant influence on financial satisfaction, because according to him, the better financial behavior a person has, the better his financial condition will be. Financial behavior is a person's behavior in managing and managing finances.

This research is intended for Indonesian professional basketball athletes. To see the financial understanding and Behavior of Indonesian professional basketball athletes, the researchers conducted a pre-survey with a questionnaire to 5 Indonesian professional basketball athletes and an interview with Danny Kosasih as the chairman of Perbasi 2019-2023. The results pre-survey show that respondents do not understand financial literacy and lack good financial behavior (Wahono \& Pertiwi, 2020; Saputra et al., 2021). They are supported by the results of interviews, which explained several incidents with former Indonesian professional basketball athletes whose lives were destroyed when their careers as professional players ended. This is due to a lack of understanding of financial literacy, and besides that, his financial behavior is also wrong. According to Danny Kosasih, former Indonesian professional basketball athletes whose lives were destroyed due to a lack of a good understanding of finances made them unable to think and behave properly. Therefore, this poor understanding and behavior make a person unable to achieve financial satisfaction. The financial satisfaction of a professional basketball athlete when he is still active as a professional athlete compared to his retirement period will undoubtedly be different. However, in this study, we want to see when someone who is still active as a professional basketball athlete can achieve reasonable financial satisfaction or not. To maintain his current financial dignity until retirement, a professional basketball athlete must have financial literacy and financial behavior. Indeed the income owned also supports the achievement of financial satisfaction one's.

This study uses models and variables like previous studies belonging to Hasibuan et al. (2018) aimed at entrepreneurs. However, the contrast to this research, this research is aimed at Indonesian professional basketball athletes from teams that are members of the IBL (Indonesian Basketball League2021) league because the league is listed on the website. The consideration of choosing Indonesian professional basketball athletes was due to the incident of former Indonesian professional basketball athletes who did not always have good luck, especially in their financial condition, so this study wanted to see how the provision of financial literacy and financial Behavior in Indonesian professional basketball athletes today is to achieve financial satisfaction. In addition, other considerations are looking at the condition of Indonesian basketball, which will start to be active again in 2021, and the implementation of the 2021 Indonesian Basketball League (IBL), and Indonesia will host the FIBA match in 2023.

\section{LITERATURE REVIEW}

\section{Financial Satisfaction}

The concept of financial satisfaction uses several indicators to measure a person's level of satisfaction, such as satisfaction with income, satisfaction with the financial situation in general, or satisfaction with the current status of life (Hira \& Mugenda, 1998). Joo \& Grable (2004) said that financial satisfaction could be seen through the objective (material) and subjective (non-material) aspects of a person's financial status as well as from his actual financial situation. For example, 
sometimes, someone who has a large enough debt feels satisfied with his financial condition. This is because financial satisfaction is subjective, and objective and the satisfaction scale of everyone must be different from one another.

\section{Financial Literacy}

Financial literacy is knowledge to manage finances in making financial decisions (Chen \& Volpe, 1998; Rizon et al., 2021). Mason \& Wilson (in Krishna et al. (2010)) say financial literacy is a person's ability to obtain, understand and evaluate relevant information to decide by understanding the financial consequences that can arise. Therefore, financial literacy is essential for every individual to avoid and face financial problems thanks to their knowledge. According to Chen \& Volpe (1998), financial literacy can be seen with four indicators: general financial knowledge, knowledge about saving and borrowing, knowledge about insurance, and investment knowledge.

\section{Financial Behavior}

According to Xiao (2008), financial behavior is related to money management. Someone who has good financial behavior tends to be more effective in using the money they have, such as generating, managing, controlling spending, investing, and paying bills on time (Hasibuan et al., 2018). According to (Potrich et al., 2016), financial behavior can be seen with four indicators, namely the use of credit cards, planned consumption, investment, and savings.

\section{Relation Between Concepts}

\section{Effects of Financial Literacy Against Financial Satisfaction}

Farida et al. (2020) showed that financial literacy significantly impacts financial satisfaction at owned research. The results in this study explain the higher the level of a person's financial literacy, the higher the level of financial satisfaction himself and vice versa. According to the study, someone who has financial literacy (Rizon et al., 2021; Saputra et al., 2021) and applies it to everyday life can make financial decisions correctly, affecting financial satisfaction.

\section{Effect of Financial Behavior on Financial Satisfaction}

Research owned by Hasibuan et al. (2018) showed that individuals who have financial behavior goodwill demonstrate a high level of financial satisfaction on her financial condition. According to the study, someone who has financial behavior goodwill shows a good financial satisfaction anyway because a better financial behavior persons will encourage him to manage finances better (Hasibuan et al., 2018).

\section{METHODOLOGY}

The type of research is associative research. Sugiyono (2019) said that the associative research method could be interpreted as explaining the influence between two or more variables. This study uses associative analysis to see the effect of financial literacy and financial behavior on financial satisfaction in Indonesian professional basketball athletes and uses a quantitative approach. The population in this study were Indonesian professional basketball athletes who were registered in the basketball league officially organized by Perbasi, namely the Indonesian Basketball League (IBL) 2021, totaling 177 Indonesian professional basketball athletes. This number is the number of players who have original Indonesian citizenship. The sampling technique used in this study is nonprobability sampling with purposive sampling. The criteria for collecting samples in this study were Indonesian professional basketball athletes who had credit cards and carried out investment activities so that respondents could answer questions in the questionnaire more accurately because they had experience in using credit cards and making investments (Nusaputra \& Basana, 2021). Financial Literacy variable has empirical indicators: Questions that measure financial intelligence related to knowledge of financial knowledge in general, knowledge of saving 
and borrowing, knowledge of insurance, knowledge of investment (Chen \& Volpe, 1998). Financial behavior variable has the empirical indicators: Statements that measure financial behavior in credit card use, planned consumption, investment, and savings (Potrich et al., 2016). The last for Financial Satisfaction variable has the empirical indicators: Statements that measure satisfaction with the level of debt owned, satisfaction with the ability to meet basic needs, satisfaction with the ability to manage finances, satisfaction with the ability to stock up funds for future interests, satisfaction with the amount of savings owned, as well as satisfaction in readiness to meet the needs of emergency funds (Hira \& Mugenda, 1998). Data Analysis Techniques for this study uses Partial Least Square (PLS).

\section{ANALYSIS AND DISCUSSION}

\section{Overview of Research Objects}

Table 1. Profile of Respondents

\begin{tabular}{|c|c|c|}
\hline Information & Total & Percentage \\
\hline \multicolumn{3}{|c|}{ Age } \\
\hline$<25$ & 50 & $42 \%$ \\
\hline $25-30$ & 59 & $50 \%$ \\
\hline$>30$ years & 9 & $8 \%$ \\
\hline Total & 118 & $100 \%$ \\
\hline \multicolumn{3}{|l|}{ Current Domicile } \\
\hline Jakarta & 43 & $36 \%$ \\
\hline Bandung & 24 & $20 \%$ \\
\hline Surabaya & 20 & $17 \%$ \\
\hline Jogja & 13 & $11 \%$ \\
\hline Bali & 14 & $12 \%$ \\
\hline Depok & 1 & $1 \%$ \\
\hline Tangerang & 3 & $3 \%$ \\
\hline Total & 118 & $100 \%$ \\
\hline \multicolumn{3}{|c|}{ Annual Income } \\
\hline$<$ Rp. $50,000,000$ & 42 & $36 \%$ \\
\hline Rp. $50,000,000$ - Rp. $250,000,000$ & 48 & $41 \%$ \\
\hline Rp. $250.000,001$ - Rp. $500,000,000$ & 24 & $20 \%$ \\
\hline$>$ Rp. $500,000,000$ & 4 & $3 \%$ \\
\hline Total & 118 & $100 \%$ \\
\hline Information & Total & Percentage \\
\hline \multicolumn{3}{|c|}{ Length of Time Being Indonesian Professional Basketball Athlet } \\
\hline$<1$ year & 5 & $4 \%$ \\
\hline $1-2$ years & 32 & $27 \%$ \\
\hline $3-4$ years & 25 & $21 \%$ \\
\hline $5-6$ years & 36 & $31 \%$ \\
\hline$>6$ years & 20 & $17 \%$ \\
\hline Total & 118 & $100 \%$ \\
\hline \multicolumn{3}{|l|}{ Other Sources of Income } \\
\hline Sponsor / Brand Ambassador & 28 & $24 \%$ \\
\hline Advertising / Endorsement & 64 & $54 \%$ \\
\hline Monthly money from parents & 10 & $8 \%$ \\
\hline Business / Entrepreneur & 21 & $18 \%$ \\
\hline Trader & 1 & $1 \%$ \\
\hline None & 33 & $28 \%$ \\
\hline \multicolumn{3}{|c|}{ Average Spending Every Month for Living Needs } \\
\hline$<10 \%$ & 10 & $8 \%$ \\
\hline $10 \%-30 \%$ & 83 & $70 \%$ \\
\hline$>30 \%$ & 23 & $19 \%$ \\
\hline Do not have a budget & 2 & $2 \%$ \\
\hline Total & 118 & $100 \%$ \\
\hline \multicolumn{3}{|c|}{ Drivers in Purchasing Investment Products First time } \\
\hline Self-desire & 98 & $83 \%$ \\
\hline Just joining friends/friends/family & 18 & $15 \%$ \\
\hline Needs & 2 & $2 \%$ \\
\hline Total & 118 & $100 \%$ \\
\hline
\end{tabular}


In this study, 177 questionnaires were distributed to respondents. However, as many as 59 questionnaires did not meet the criteria. So that only 118 questionnaires were in this study. The following is additional information on the respondent's profile.

After the research results have been obtained, they will be processed with Partial Least Square. Here are the results of the path analysis in Figure 1, the evaluation of the goodness of fit outer model in Table 2, and the results of reliability in Table 3.

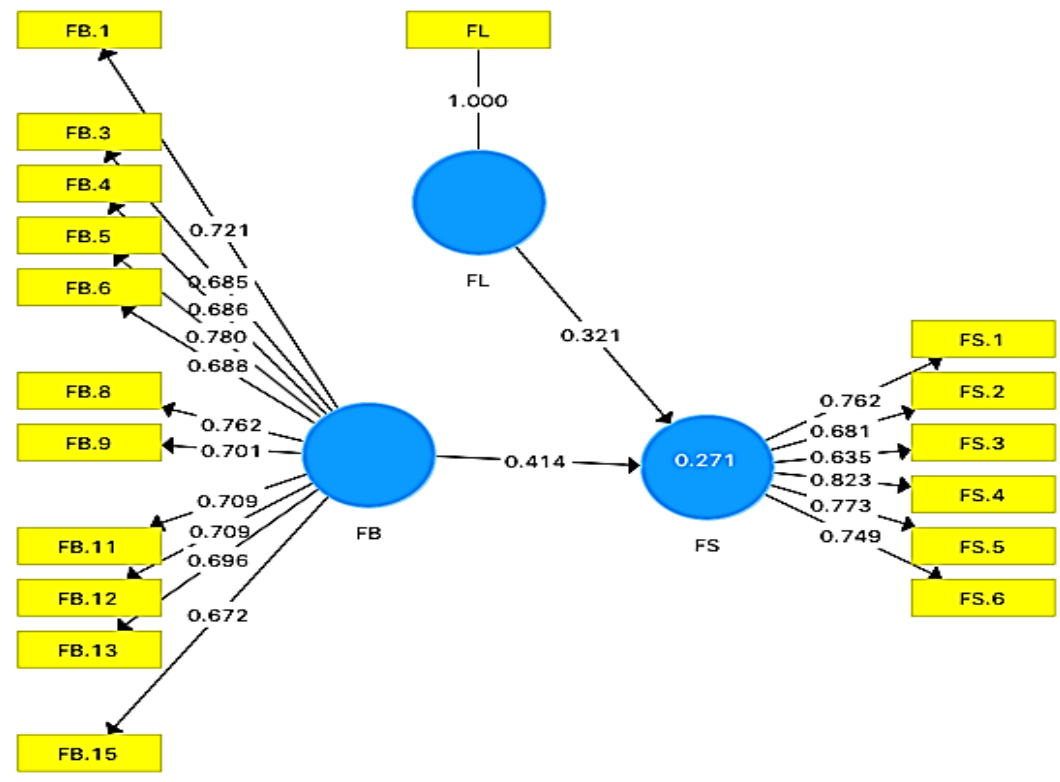

Figure 1. The Results of Path Analysis

Table 2. The Value of Outer Loading

\begin{tabular}{ccc}
\hline Variable & Indicator & Outer Loading \\
\hline Financial Literacy & FL & 1 \\
\hline Financial Behavior & FB.1 & 0.721 \\
& FB.3 & 0.685 \\
& FB.4 & 0.686 \\
& FB.5 & 0.780 \\
& FB. & 0.688 \\
& FB. & 0.762 \\
& FB.9 & 0.701 \\
& FB.11 & 0.709 \\
& FB.12 & 0.709 \\
& FB.13 & 0.696 \\
& FB.15 & 0.672 \\
\hline Financial Satisfaction & FS.1 & 0.762 \\
& FS.2 & 0.681 \\
& FS.3 & 0.635 \\
& FS. 4 & 0.823 \\
& FS.5 & 0.773 \\
& FS.6 & 0.749 \\
\hline
\end{tabular}

Table 3. Value AVE, Composite Reliability, and Cronbach's Alpha

\begin{tabular}{cccc}
\hline Variable & AVE & Composite Reliability & Cronbach's Alpha \\
\hline Financial Literacy & 1 & 1 & 1 \\
Financial Behavior & 0.505 & 0.918 & 0.903 \\
Financial Satisfaction & 0.548 & 0.878 & 0.835 \\
\hline
\end{tabular}


Table 4. The Values of Cross Loading

\begin{tabular}{cccc}
\hline & FL & FB & FS \\
\hline FL & 1 & -0.011 & 0.316 \\
FB.1 & -0.011 & 0.721 & 0.275 \\
FB.3 & 0.036 & 0.685 & 0.309 \\
FB.4 & 0.012 & 0.686 & 0.354 \\
FB.5 & 0.070 & 0.780 & 0.263 \\
FB.6 & -0.056 & 0.688 & 0.213 \\
FB.8 & 0.043 & 0.762 & 0.340 \\
FB.9 & -0.038 & 0.701 & 0.203 \\
FB.11 & -0.055 & 0.709 & 0.235 \\
FB.12 & 0.047 & 0.709 & 0.388 \\
FB.13 & -0.1 & 0.696 & 0.180 \\
FB.15 & -0.126 & 0.672 & 0.290 \\
FS.1 & 0.292 & 0.223 & 0.762 \\
FS.2 & 0.212 & 0.141 & 0.681 \\
FS.3 & 0.094 & 0.318 & 0.635 \\
FS.4 & 0.392 & 0.291 & 0.823 \\
FS.5 & 0.157 & 0.432 & 0.773 \\
FS.6 & 0.218 & 0.354 & 0.749 \\
\hline
\end{tabular}

Table 5. Value Fornell-Larcker Criterion

\begin{tabular}{cccc}
\hline & FL & FB & FS \\
\hline FL & 1 & & \\
FB & -0.011 & 0.711 & \\
FS & 0.316 & 0.410 & 0.740 \\
\hline
\end{tabular}

The test convergent validity value of outer loading and the average variance extracted (AVE) must indicate a value $>0.5$. Based on Table 2 . and Table 3 . The outer loading and AVE values on all indicators have shown values $>0.5$. So, all these indicators are valid and can be used because they have met the requirements of convergent validity. In discriminant validity aims to see how much the different levels of a variable with other variables in the research model and viewed through crossloading and Fornell-Larcker criterion. The loading factors of an indicator on a variable must be higher than the loading of other variables. In the Fornell-Larcker criterion, each variable's squared root AVE value must be greater than its correlation with other variables. Based on Table 4 . the value crossloading has shown a number $>0.5$, and in Table 5 . the Fornell-Larcker criterion has been met by each variable, and the indicator of each variable has the highest loading on the variable. Therefore, all these indicators are valid because they have met the requirements of discriminant validity and can be used for analysis. This shows that all the variables from this study have met discriminant validity and are valid. Evaluation of the Goodness of the Inner Model for the value of r-square is useful to see how much exogenous variables can explain endogenous variables in research. The value of $\mathrm{R}$-square on the FS variable is 0.271 . This illustrates that financial literacy and financial behavior variables can explain the variable financial satisfaction of 0.271 or $27.1 \%$; results of the hypothesis test on Table 6.

Table 6. The Value $t$-statistic

\begin{tabular}{lcccc}
\hline Effect & Original Sample & $\boldsymbol{t}$-statistic & $\boldsymbol{P}$-values & Conclusion \\
\hline Financial literacy> Financial Satisfaction & 0.321 & 3.699 & 0.000 & Significant \\
Financial behavior> Financial Satisfaction & 0.414 & 4.961 & 0.000 & Significant \\
\hline
\end{tabular}

Results in this study showed that financial literacy has a significant effect on financial satisfaction. Financial literacy can be seen from a person's knowledge about finance in general, saving and borrowing, insurance, and investment knowledge. With an understanding of financial literacy, of course, individuals can make the right and wise decisions. These decisions will impact one's satisfaction with their financial condition, namely financial satisfaction. With sufficient financial literacy, he will be able to think and compare all forms of possibilities that exist so that he does not make wrong decisions and can achieve financial satisfaction. 
Based on the results obtained in this study, the respondents have sufficient financial literacy. These results indicate that the respondents in this study know about finance in general, saving and borrowing, insurance, and sufficient investment knowledge. The knowledge possessed by the respondents can be applied in making appropriate financial decisions and certainly has an impact on the financial condition of the respondents so that the financial satisfaction of the respondents can be achieved. The results of this study are in line with the research of Ali et al. (2014) conducted in Malaysia and Falahati et al. (2012), which was aimed at 700 students from 11 universities in Malaysia, which showed that financial literacy influenced financial satisfaction. Financial literacy helps someone to achieve financial satisfaction. Understanding good financial literacy in Indonesian professional basketball athletes can undoubtedly help them avoid financial problems. With the knowledge he has, he can achieve reasonable financial satisfaction.

Furthermore, the results in this study indicate that financial behavior has a significant effect on financial satisfaction. If the respondent has good financial behavior, it will also show good financial satisfaction. Apart from the questions on the results questionnaire, the respondents' financial behavior was supported by respondents' answers regarding the monthly expenditure budget. The average monthly expenditure of respondents to meet their daily needs is $<10 \%$ and ranges from $10 \%-30 \%$. The budget amount is considered very good because the allocation of income for daily living expenses is $60 \%-70 \%$ of income (Trisnaningsih \& Widyasari, 2010). The expenditure budget shows that respondents understand how to manage their income and feel they can fulfill the goals that have been set to direct themselves in achieving financial satisfaction.

The results of this study are in line with Hasibuan et al. (2018) \& Farida et al. (2020), which show the results of financial behavior have a significant influence on financial behavior. The better a financial behavior person's means that he has been able to manage his finances. With his ability to manage finances, he will achieve financial satisfaction because he feels that what he has done is the right thing for his financial condition. According to Hasibuan et al. (2018), someone who has good financial behavior will encourage himself to manage his financial condition better for his future. Respondents in this study can achieve financial satisfaction because they have good financial behavior. This is because he can act appropriately on the money he has to feel satisfied.

\section{CONCLUSION AND RECOMMENDATIONS}

Based on the results of the analysis and discussion in this study, it can be concluded. First, financial literacy significantly affects financial satisfaction in Indonesian professional basketball athletes. Second, financial behavior significantly affects financial satisfaction in Indonesian professional basketball athletes. Based on the results of the analysis, discussion, and conclusions in this study, the suggestions that can give are as follows: Indonesian professional basketball athletes are expected to have good financial literacy and financial behavior to be optimal in managing their current finances, and the future, to achieve financial satisfaction. For the managers of the Indonesian professional basketball team, it is hoped that they can provide counseling or training related to financial literacy and financial behavior so that athletes can find out the best and right way to manage their finances to achieve financial satisfaction.

\section{REFERENCES}

Ackert, L.F., \& Deaves, R. (2010). Behavioral Finance: Psychology, Decision-Making, and Markets. Mason, Ohio, US: South-Western Cengage Learning.

Ali, A., Rahman, M.S., \& Bakar, A. (2014, February 16). Financial Satisfaction and the Influence of Financial Literacy in Malaysia. Social Indicators Research, 120(1), 137-156.

Arifin, A.Z. (2018). Influence Factors toward Financial Satisfaction with Financial Behavior as An Intervening Variable on the Jakarta Workforce Area. European Research Studies Journal, XXI(1), 90-103.

Chen, H., \& Volpe, R. (1998). An Analysis of Personal Literacy among College Students. Financial Services Review (7), 2:107.

CNN Indonesia. (2020, February 17). Michael Jordan, A More Successful Athlete in Retirement. Retrieved from CNN Indonesia: https:/www.cnnindonesia.com/olahraga/20200216153415-178-475104/michael-jordan-atletyang-Dari-hasil-di-masa-pensiun 
The House of Representatives of the Republic of Indonesia. (nd). Law of the Republic of Indonesia. Retrieved from dpr.go.id: https://www.dpr.go.id/dokjdih/document/uu/45.pdf

Falahati, L., Sabri, M.F., \& Paim, L.H. (2012). Assessment a Model of Financial Satisfaction Predictors: Examining the Mediate Effect of Financial Behavior and Financial Strain. World Applied Sciences Journal, 190-197.

Farida, M.N., Soesatyo, Y., \& Aji, T.S. (2020). Influence of Financial Literacy and Use of Financial Technology on Financial Satisfaction through Financial Behavior. International Journal of Education \& Literacy Studies, 9(1), 86-95.

Hasibuan, B.K., H.R., W.A., \& Lubis, Y.M. (2018, January). Financial Literacy and Financial Behavior as a Measure of Financial Satisfaction. Advances in Economics, Business and Management Research (AEBMR), 46, 503-506.

Hira, T.K., \& Mugenda, O.M. (1998, January). Predictors of Financial Satisfaction: Differences Between Retirees And Non-retirees. Journal of Financial Counseling and Planning, 9(2), 75-84.

Joo, S.-h., \& Grable, JE (2004). An Exploratory Framework of the Determinants of Financial satisfaction. Journal of Family and Economic Issues 25, 25-50.

KBBI. (nd). Professional. Retrieved from Big Indonesian Dictionary (KBBI): https://kbbi.web.id/profesional

Krishna, A., Sari, M., \& Rofaida, R. (2010). Analysis of Financial Literacy Levels Among Students and Factors Influencing It (Survey of Indonesian Education University Students). Proceedings of The 4th International Conference on Teacher Education, 552-560.

Nusaputra, F., \& Basana, S. R. (2021). The Effect of Agency Costs, Ownership Structure, Signaling, Investment Opportunities, Size, Financial Leverage, and Profitability on Dividend Policy of Companies Listed In Indonesian Stock Exchange. International Journal of Financial and Investment Studies, 1(2), 109120. https://doi.org/10.9744/ijfis.1.2.109-120

Pervasive. (nd). Indonesian Basketball League (IBL). Retrieved from perbasi: https://perbasi.or.id/indonesianbasketball-league-ibl/

Rizon, R., Anastasia, N., \& Evelyn. (2021). The Influence of Demography, Social Media, Risk Attitude, and Overconfidence on the Financial Literacy of Users Social Media in Surabaya. International Journal of Financial and Investment Studies (IJFIS), 2(1), 10-19. https://doi.org/10.9744/ijfis.2.1.10-19

Rosyidan. (2016, September 17). Guaranteeing the Future of Athletes (Darius Miles, Newest Ex-NBA Player to Bankrupt). Retrieved from MAINBASKET: https://www.mainbasket.com/r/89/menjamin-masa-dalamatlet-darius-miles-eks-player-nba-terbaru-yang-bangkrut

Saputra, J., Astuti, D., \& Pertiwi, D. (2021). Effect of Financial Literacy, Risk Attitude and Saving Motives to Disposition Bias on Mutual Funds Investors. International Journal of Financial and Investment Studies, 2(1), 27-33. https://doi.org/10.9744/ijfis.2.1.27-33

Sugiyono. (2019). Quantitative Research Methodology. (Setiyawami, Ed.) Bandung: Alfabeta.

Trisnaningsih, S., \& Widyasari, F. (2010, January). Family Financial Management and Planning for Housewives in the Siwalankerto Region, Surabaya. Journal of Accounting Strategy, 2.

Wahono, H. K., \& Pertiwi, D. (2020). Pengaruh Financial Literacy, Materialism, Compulsive Buying terhadap Propensity to Indebtedness. International Journal of Financial and Investment Studies, 1(1), 1-14. https://doi.org/10.9744/ijfis.1.1.1-14

Van-Praag, B.M., \& Ferrer-i-Carbonell, A. (2011). Happiness Economics: A New Road to Measuring and Comparing Happiness. The Attitude of Mainstream Economics Toward Happiness, 6(1), 1-97.

Xiao, JJ (2008). Applying Behavior Theories to Financial Behavior. In JJ Xiao, Handbook of Consumer Finance Research (pp. 69-79). Kingston, RI, US: Springer Science+Business Media, LLC.

Yuwanto, L., \& Sutanto, N. (2012). Psychological Description of Adolescent Athletes Based on EPPS Structure Analysis. 3Mindset, 115-122. 